\title{
Hazards of deep-sea fishing ${ }^{1}$
}

\author{
R. S. F. SCHILLING \\ London School of Hygiene and Tropical Medicine TUC Centenary Institute of \\ Occupational Health
}

\begin{abstract}
Schilling, R. S. F. (1971). Brit. J. industr. Med., 28, 27-35. Hazards of deep-sea fishing. During the nineteenth century sailing smacks suffered heavy losses at sea. Their replacement by steam trawlers and motor vessels reduced casualties to both ships and men. The accident mortality of fishermen in England and Wales has been grossly underestimated by the Registrar General of Births and De aths because all but a few deaths at sea are reported separately to the Registrar General of Shipping and Seamen and are not taken into account in calculating mortality rates. By including deaths at sea in the period 1959-63, fishermen's standardized mortality ratio for accidents is increased from 466 to 1726 . Between 1958 and 1967, 92 fishermen on British trawlers lost their lives as a result of casualties to vessels; and 116 from individual accidents, mostly by drowning. The importance of individual accidents is emphasized by the fact that in years when there was no heavy loss of life from vessel casualties, fishermen's fatal accident rates were at least twice those of coal miners and more than 20 times the rate of men in manufacturing industries. Crews of distant-water vessels have higher fatal accident rates than crews of near- and middle-water vessels ( 2.3 against 1.8 per 1000 man-years); for skippers and mates on distant-water vessels the rate is 3.2 per 1000 man-years which is higher than the corresponding rate of 2.6 for deck-hands and almost double that for other crew members.

In 47 out of 90 trawlers lost or seriously damaged, the cause of the casualty was attributable to negligent navigation. Fatigue due to excessively long hours of work may contribute to casualties to both vessels and individuals. The Committee of Inquiry into Trawler Safety set up by the British Government after the loss of three trawlers in 1968 made many recommendations for higher standards of design, construction, and stability of vessels for the deep-sea fleet and for a reduction in the hours of work for deck-hands. The Committee also recommended the supply of a support ship at sea offering special services such as weather forecasting, medical and technical aid, and the provision of occupational health services for fishermen in port.
\end{abstract}

In the middle of the nineteenth century, when Ernestine Henry was a child, trawl fishing was developing rapidly in Britain. The newly discovered fishing grounds in the North Sea could be fully exploited because the advent of the railway made it possible to despatch fish from east coast ports to the markets of London and the midland towns. The fishing vessels of those days were sailing smacks owned or part-owned by humble and often illiterate men,

'The Ernestine Henry Lecture delivered at the Royal College of Physicians, London on 27 February 1970. many of whom had migrated from southern England to reap the harvest in the North Sea. Between 1863 and 1871 about 1000 smacks were operating from the east coast ports, and, on average, 120 of these vessels were lost every year (March 1953). Since the number of men lost and the size of the population at risk are not known, mortality rates cannot be calculated. However, contemporary writers leave no doubt that deep-sea fishing was a highly dangerous occupation. Charles Dickens graphically portrays the hazardous life of east coast fishermen. The inquisitive young David Copperfield drags out of Mr. Peggoty that 
Mr. Gummidge, his partner, died at an early age and that Hams father and Emily's father were both 'drowndead". In the same period, Kipling tells a dramatic story in Captains Courageous of schooners from Gloucester, Massachusetts fishing the Grand Banks off Newfoundland. These vessels fished with lines and hooks from small dory boats. Kipling gives a vivid account of a memorial day for fishermen lost at sea, with the names of the dead read out and a collection taken for widows and orphans.

Looking for some measure of the accident mortality of fishermen in the nineteenth century, I took a cue from Kipling's story and got records of the numbers of Gloucester men lost at sea between 1874 and 1881 and an estimate of their population. Their annual losses were approximately 22 per 1000 men at risk. Today very few fishermen are drowned because schooners have been replaced by the safer motor vessels which confine their voyages to nearer and less dangerous waters, largely hecause of the decline in commercial fishing.

I have also got a measure of the mortality of British deep-sea fishermen during the last century from $\mathrm{Mr}$. Gillett of Hull University. Searching through old records he found that in Grimsby, one of the four largest fishing ports in the British Isles, 1024 men were lost between 1880 and 1893 when most vessels were sailing smacks. With an estimated population of 6000 , the annual accident mortality rate at sea was 11 per 1000 , which is about four or five times the contemporary rate for Grimsby fishermen (Moore, 1969b). By comparison, the present figures are relatively low and have been acceptable, particularly to the older generation of fishermen who adopt a fatalistic attitude to accidents, which they regard as an inevitable consequence of their occupation.

\section{Occupational mortality}

The mortality rates of trades and professions are published every 10 years or so by the Registrar General of England and Wales. The rates for fishermen would not encourage anyone to pay particular attention to their health and safety. From these published rates it appears that since the end of the nineteenth century, fishermen's death rates from all causes have been similar to, or slightly in excess of, those of all males. Their accident mortality has been given as two or three times that of other men. In 1949-53, the latest figures to be published, 563 fishermen aged 20 to 64 died from all causes, whereas 458 deaths would have been expected on the mortality experience of all males; this gives a standardized mortality ratio (SMR) of 123 (Registrar General, 1958). The SMR for accidents (less those occurring in the home or on the road) was 336 , i.e., more than three times that of other men. These accidents are accepted as an index of occupational risk although they include a very small proportion of fatalities not connected with work. On these data, fishing in England and Wales had a lower accident mortality than nine other occupations (Fig. 1). The highest mortality occurs in commissioned officers in the armed Forces, followed by miners (not coal), constructional engineers, railwaymen, and other occupations which are accepted as dangerous and protected by safety legislation. On the face of it. the mortality figures for fishermen are not very alarming. particularly in view of the additional risks of working at sea. Ogle (1885), the first Registrar General to comment on fishermen's mortality rates, warned that they must be accepted with some hesitation because of the uncertainty attached to the numbers of both living and dead. The population is obtained from the national census taken every 10 years and based on householders returns. It includes both sea and inland waters fishermen. Attempts are made to include fishermen at sea or in harbour at the time of the census, but some are always likely to be missed. The real uncertainty arises in counting the number who die, and here even a small number missed will lead to a substantial underestimate of mortality.

In 1965, my department at the London School of Hygiene and Tropical Medicine was invited by the White Fish Authority to investigate Dogger Bank itch, a skin condition occurring among Lowestoft trawlermen (Newhouse. 1966). While spending six days at sea on a trawler, I became aware of hazards other than skin disease, in particular, the very high risk of accidents. Tunstall (1962) first drew attention to the relatively large number of deaths at sea using figures that used to be published in the Ministry of Labour Gazette. It became clear that the accident mortality rate published by the Registrar General of England and Wales does not take account of deaths at sea which are recorded separately by the Registrar

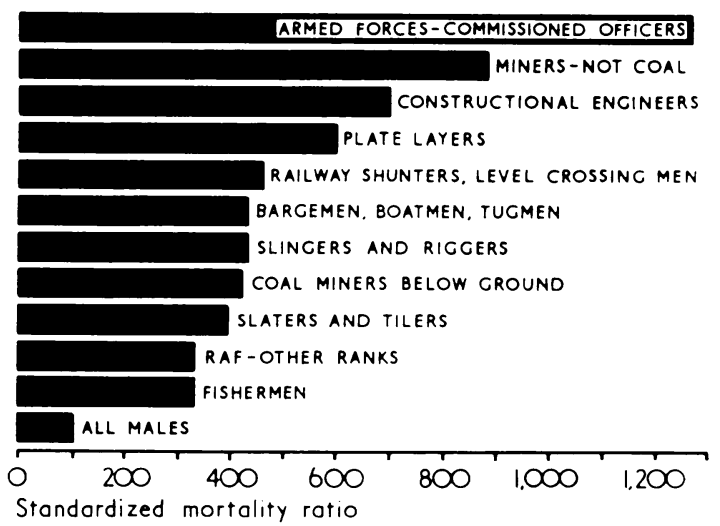

Fici. 1. Other accidents. Standardized mortality ratios for males in England and Wales aged 20-64, 1949-53. 
General of Shipping and Seamen. Using only these deaths, fishermen had an accident mortality at least twice that of coal miners and in contrast to the figures published by the Registrar General of England and Wales which indicated that the accident mortality of fishermen is less than that for coal miners (Schilling, 1966).

In calculating mortality rates, deaths at sea cannot simply be added to those recorded hy the Registrar General of Births and Deaths because there are occasions when the records of the two Registrars may be duplicated. This could happen in the case of a fisherman dying in harbour or on a ship wrecked near the coast, or of a body brought ashore or washed up by the sea. The next step was to find the extent of the overlap so that more accurate mortality rates could be calculated. Copies of the death certificates of 631 fishermen who died in the quinquennium 1959-63 were obtained from the Registrar General for England and Wales. The Registrar General for Shipping and Seamen supplied the names of 168 fishermen who died at sea during the same period. Only six deaths were duplicated and, after omitting 21 false entries, there was a total of 772 deaths for men aged 15 to 64 years. The commonest cause of death was accidents at work which numbered 150 . closely followed by coronary heart disease at 146 (Table 1). The inclusion of the deaths at sea raises the SMR for accidents at work from 466 to 1726

\section{TABLE 1}

Standardized Mortality Ratios for Fishermen in ENGLand AND Wales Aged 15-64 Including Deaths at Sea 1959-63

\begin{tabular}{l|cc|c}
\hline & \multicolumn{2}{|c|}{ No. of deaths } & \\
Cause of death & Observed & Expected & SMR \\
\hline Accidents at work & 150 & 9 & 1726 \\
Other accidents \& suicides & 53 & 31 & 169 \\
Hypertension & 22 & 10 & 215 \\
Cancer of lung or bronchus & 97 & 51 & 191 \\
Cancer of stomach & 29 & 15 & 189 \\
Bronchitis & 46 & 31 & 147 \\
Coronary heart disease & 146 & 112 & 130 \\
Other causes & 229 & 178 & 77 \\
\hline All causes & 772 & 437 & 177 \\
& & & \\
\hline
\end{tabular}

The relatively high SMR for other accidents and suicides might be taken to indicate that fishing attracts men prone to accidents and self destruction. The excessive risk occurs only among older men and could well be due to the disruptive effects of this type of work on their way of life.

The high SMRs for cancer of the lung and bronchus and bronchitis are likely to be due to heavy cigarette smoking. This may also account for the moderate excess of deaths from coronary heart disease; fishermen also have a high SMR for hypertension.
(Schilling, Walford, and Wood, 1969). The risk is 17 times greater than that of all men in England and Wales, which is very different from the two- or threefo'd excess previously recorded. The se figure s are for all fishermen including the relatively small number who fish inland and inshore waters. The inclusion of the latter does not invalidate these rates being used as a rough measure of the mortality of deep-sea fishermen; if anything, it is an underestimate because inshore and inland fishermen are less at risk than men fishing the high seas.

In the days of sailing vessels, the mortality of fishermen was undoubtedly very high indeed. In the era of the motor vessel, loss of life has been very much lower, but these published rates have been misleadingly low, which may help to explain the lack of attention by Government, employers, and unions to health and safety standards in the fishing industry. Since the true facts have emerged, more effective action has been taken.

In 1967, following a preliminary report (Schilling, 1966) on fishermen's fatal accident rates, the Board of Trade set up a working group which, in 1969, produced a Recommended Code of Safety for Fishermen on Trawlers. Later, an interdepartmental committee was appointed to consider the need for research into the technical aspects of trawler safety. Early in 1968, before either of these committees had had time to complete their tasks, three distant-water trawlers from Hull sank with the loss of 58 men. These disasters, which occurred within the space of a few weeks, caused great public concern and immediate action followed. The President of the Board of Trade appointed a Committee of Inquiry into Trawler Safety (CITS) ${ }^{1}$ under the chairmanship of Admiral Sir Deric Holland Martin whose wide terms of reference were 'to examine the major factors affecting the safety of deep-sea trawlers and their crews and to make recommendations'.

One of the committee's first tasks was to get facts which would show the extent, nature, and causes of hazards to both men and vessels. Statistics were from two sources. The Registrar General of Shipping and Seamen provided figures on deaths and non-fatal accidents at sea during the period 1958-67 and the Board of Trade on casualties to vessels between 1957 and 1966. Each period was the longest for which satisfactory information was available. The deep-sea fleet comprises some 170 distant water vessels which fish mainly off Newfoundland, Greenland, Iceland, North Norway, and North Russia; and some 380 near- and middle-water trawlers which fish around the Faroes, in the North Sea, and to the

'I was privileged to serve on this committee and many of the figures quoted are taken from its Final Report on Trawler Safety (Holland-Martin, 1969). Many of my personal observations are based on experience gained while serving on this committee. 
west of the British Isles. The distant-water vessels are 140 feet $(42.5 \mathrm{~m})$ or more in length and are mostly side trawlers; these vessels are gradually heing replaced by stern trawlers which provide safer and healthier conditions of work, because the men work for the most part under cover and are not required to lean over the side while working the fishing gear. Moreover, the stern trawler has a high freeboard which favours stability, an important factor in the safety of the vessel. The fishing industry prefers the stern trawling design for the larger vessels and it is unlikely that any more side trawlers of over 140 feet in length will be built. Among the smaller vessels which fish near and middle waters, the side trawler is still preferred for technical reasons.

\section{Accidents at sea}

Fatal accidents were classified as individual accidents, that is, men lost overboard or fatally injured by machinery, and men lost as a result of vessel casualties, that is, founderings, capsizings, missing ves:els, explosions and fires. In both the distant-, near-, and middlewater trawlers, vessel casualties causing the loss of 92 men were responsible for fewer deaths than individual accidents which totalled 116. This is an important and surprising fact which indicates that accidents to individual crew members, occurring when their ships are not necessarily in danger, present as serious a problem as the disasters involving the losses of vessels and their crews. The addition of the figures for 1968 and 1969, which include the 58 men lost in three ships, radically changes the picture for the distant water vessels (Fig. 2); indeed, one of the characteristics of British trawler-men's fatal accident rates is their wide fluctuation (Figs. 3 and 4). During the period 1958-67, 74 of the 116 individual accidents were men lost overboard.

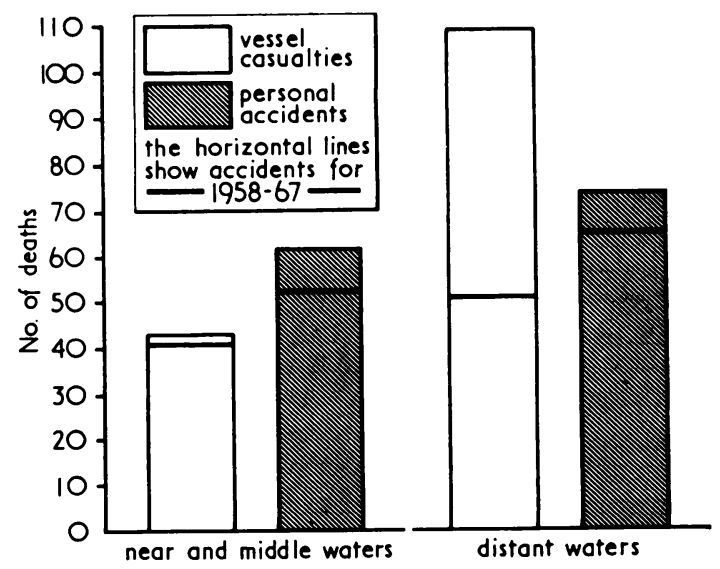

FIG. 2. Fatal accidents on deep-sea trawlers in Great Britain, 1958-69.

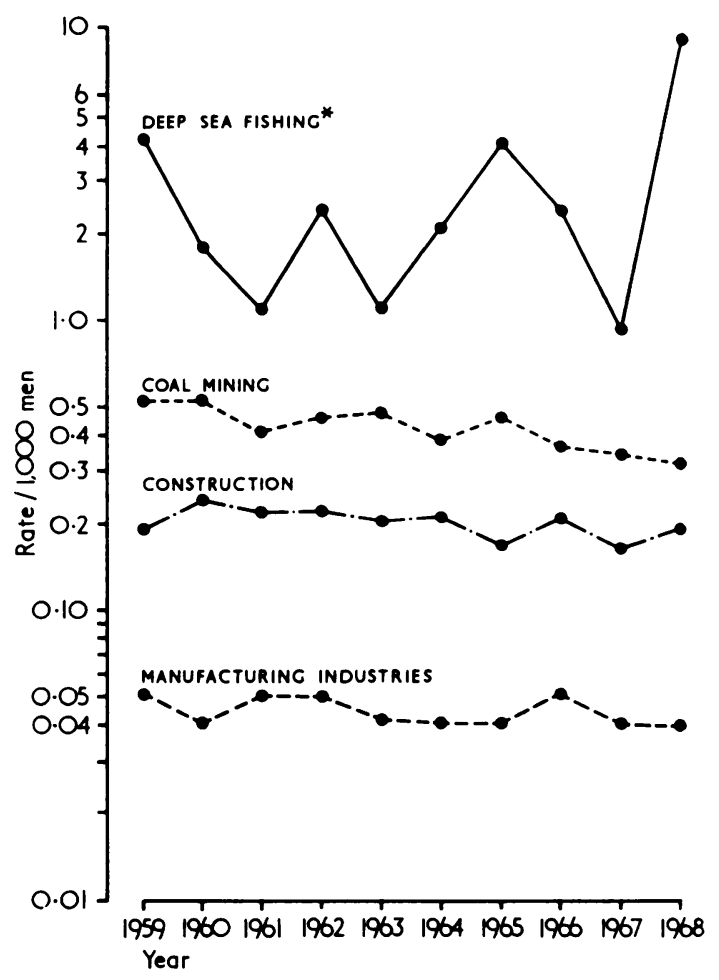

FIG. 3. Fatal accident rates per 1000 men at risk.

(Sources-Registrar General Shipping and Seamen: Medical Statistics Branch National Coal Board; H.M. Factory Inspectorate)

* These rates are for accidents at sea only; it is estimated that the inclusion of deaths ashore would increase these yearly rates by about $0 \cdot 2$ per 1000 .

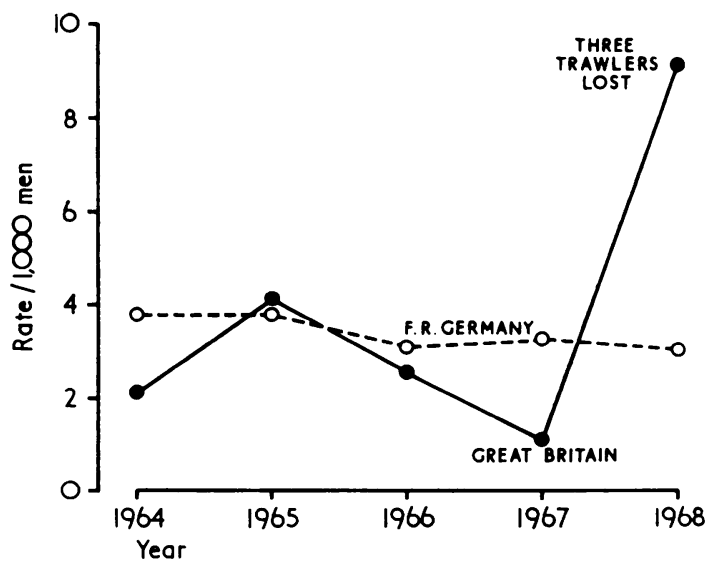

FIG. 4. Fatal accident rates per 1000 men at risk in deepsea trawlers. 
Eighteen were due to accidents on deck and 10 were known or suspected suicides. Drowning was also the major cause of death among the 92 men lost from casualties to vessels (Table 2). Seventeen men died as a result of fire and explosions, 12 in the St Finbarr, a modern stern trawler which caught fire at sea. While this type of vessel, by its very design, is a safer and healthier ship than the side trawler, it carries special hazards from work in refrigerated spaces and, apparently, a greater fire risk than occurs in older vessels. There are too few stern trawlers (approximately 33 out of 170 vessels in the distantwater fleet) to draw reliable conclusions about their relative safety; nevertheless, death rates from personal accidents at 0.8 per 1000 man-years have been less than those of side trawlers which have a rate of 1.4 per 1000 man-years (Table 3 ). The crews of distantwater side trawlers have higher fatal accident rates than crews of near- and middle-water vessels $(2.3$ as against 1.8 per 1000 man-years). This is hardly surprising for the latter spend less time at sea and seldom fish the distant and dangerous waters of the Arctic.

\section{Non-fatal accident rates by type of trawler}

The figures for non-fatal accident rates are based on returns made by skippers. They may be inaccurate in two respects and must therefore be interpreted with reserve. First some injuries are not recorded (Moore, 1969a) and secondly the cause and nature may be inaccurately described. Non-fatal accident rates follow the same trend as fatalities. They are highest for the distant-water side trawlers (155 per 1000 man-years) and by far the lowest for stern trawlers (40 per 1000 man-years) with the nearand middle-water side trawlers having an intermediate rate of 91 per 1000 man-years.

\section{Fatal accident rates by occupation}

The deck-hands on a side trawler, which shoots and tows its net over the side, work in all seasons on an open deck only a few feet above the sea. They run a serious risk of falling overboard or of being swept

TABLE 2

Number of Deaths on Deep-sea Trawlers in Great Britain by Type of Vessel Casualty, 1958-67

\begin{tabular}{ll|r}
\hline Vessel $\begin{array}{l}\text { missing } \\
\text { strandings }\end{array}$ & 41 \\
\multicolumn{2}{c|}{$\begin{array}{l}\text { founderings } \\
\text { collisions }\end{array}$} & 20 \\
Fires and explosions & 5 \\
- & 17 \\
\hline & Total & 92 \\
\hline
\end{tabular}

TABLE 3

Death Rates/1 000 Man-years among Deep-sea Trawler Crews in Great Britain 1958-67

\begin{tabular}{l|c|c}
\hline \multicolumn{1}{c|}{ Type of trawler } & $\begin{array}{c}\text { Vessel } \\
\text { casualties }\end{array}$ & $\begin{array}{c}\text { Personal } \\
\text { accidents }\end{array}$ \\
\hline Side \{ near- and middle-water & 0.8 & 1.0 \\
distant-water & 0.9 & 1.4 \\
0.8
\end{tabular}

'Produced by 12 deaths from a fire on one trawler

away by heavy seas. These dangers are reflected in the breakdown of deaths by occupations (Table 4). In distant-water vessels, which encounter the most severe weather conditions, the death rates for skippers and mates (3.2 per 1000 man-years) and for bo'suns and deck-hands ( 2.6 per 1000 man-years) were noticeably higher than the rates for engineers, greasers, and firemen (1.8 per 1000 man-years) and cooks and radio officers (1.6 per 1000 man-years). What is surprising is the relatively high rate for skippers and mates compared with the deck crew who are generally thought to be more at risk. It is difficult to examine the mortality of skippers and mates separately because many of them change from one job to the other. The skipper works mostly on the bridge where there is little danger, apart from a casualty to his vessel, whereas the mate probably does the most dangerous job of all the deck crew. This is the most likely explanation for the high accident rate of this group of officers.

TABLE 4

Deaths on Side Trawlers by Capacity 1958-67

\begin{tabular}{|c|c|c|}
\hline & \multicolumn{2}{|c|}{ Deaths/1 000 man-years } \\
\hline & $\begin{array}{l}\text { Near- } \\
\text { and } \\
\text { middle- } \\
\text { water }\end{array}$ & $\begin{array}{c}\text { Distant- } \\
\text { water }\end{array}$ \\
\hline \multirow{4}{*}{$\begin{array}{l}\text { Skippers and second hands } \\
\text { Bo'sun, deck-hands, spare } \\
\text { hands, deck learners } \\
\text { Engineers, greasers, firemen } \\
\text { Cooks, galley boys, radio } \\
\text { officers }\end{array}$} & 1.8 & $3 \cdot 2$ \\
\hline & 1.9 & $2 \cdot 6$ \\
\hline & 1.8 & $1 \cdot 8$ \\
\hline & 1.4 & $1 \cdot 6$ \\
\hline
\end{tabular}

\section{Comparison with fatal accident rates in other industries}

The deep-sea fisherman is exposed to risk for much longer periods than workers on land-based industries; he may be at sea for weeks at a time and any 
accident occurring during this period will be recorded as an accident at work. For this reason, it has been suggested that fishermen's accident rates are not comparable with those of men in other industries. But their longer exposure to risk is inherent in the nature of their work and their high mortality rates from accidents reflect the serious nature of the safety problem in comparison with other types of employment (Fig. 3). Even in the years 1961, 1963, and 1967 when there was no heavy loss of life from casualties to vessels, the fishermen's fatal accident rates were at least twice those of coal miners, five times those of constructional workers, and more than 20 times the rate for men in the manufacturing industry. This high mortality risk for deep-sea fishermen is often regarded as inevitable. As one shipbuilder wrote after the loss of the three Hull trawlers, 'Let the Island Race not forget just how cruel the sea is' (Lithgow, 1968). The evidence we heard at the Committee of Inquiry "convinced us that the majority of accidents in the fishing industry - whether to ships or to individuals - arise to a greater or lesser degree from human error and may be prevented.

\section{Casualties to vessels}

Between 1957 and 1966, 90 trawlers were totally lost or involved in serious casualties. The safety of a vessel depends primarily on its overall design, that is to say, its size and type, whether it is a side or a stern trawler. Its safety also depends on other factors such as stability, freeboard (height of the deck amidships above the sea), weather-tight integrity, and structural protection against fire. Defects in design which may cause ships to founder, capsize, or catch fire were not the most common cause of casualties during this period; 47 out of the 90 were attributable to negligence in navigation resulting in strandings and collisions (Table 5). In nearly three out of every 10 cases of strandings or collisions, trawlers were not being navigated by certificated officers (skippers or mates) at the time of the accident. Higher standards

TABLE 5

Causes of Serious Casualties to 90 Deep-sea TRAWLERS 1957-66

\begin{tabular}{|c|c|c|c|}
\hline & Lost & Damaged & Total \\
\hline $\begin{array}{l}\text { Negligent navigation } \\
\text { Fires and explosions } \\
\text { Other strandings \& collisions } \\
\text { Founderings } \\
\text { Capsized and missing } \\
\text { Other causes }\end{array}$ & $\begin{array}{r}26 \\
4 \\
4 \\
5 \\
4 \\
-\end{array}$ & $\begin{array}{r}21 \\
14 \\
5 \\
3 \\
-4\end{array}$ & $\begin{array}{r}47 \\
18 \\
9 \\
8 \\
4 \\
4\end{array}$ \\
\hline Total & 43 & 47 & 90 \\
\hline
\end{tabular}

of navigation and seamanship could reduce this type of casualty; hence the CITS endorsed the recommendation made in 1961 by the Fleck Committee, that distant-water trawlers should carry a third certificated officer. This could also reduce the hours of work of skippers who may spend as much as 18 hours a day on the bridge during fishing. The fatigue which follows such long spells of duty may have adverse effects on judgement and hence on the safety of the vessel and crew.

Vessel casualties of all types were more common among the older trawlers (Table 6). For all causes, the casualty rate per 1000 trawler-years was 2.55 for vessels more than 21 years old, which is three times the rate $(0.86)$ for the newer trawlers. This difference should not be attributed solely to the better design and equipment of the more modern vessels. Usually the more effective people are attracted to and selected for the more efficient workplaces where they have greater opportunities of fulfilment. As doctors we see examples of this 'natural selection' in hospitals and in general practice, resulting in a wide gap between the standards of the best and of the worst. In the trawler industry the best skippers tend to get command of the most modern and efficient vessels. They attract good crews and keep them together as a team (Moore, 1969a). The better safety record of more modern trawlers is most likely to be due to the combined effects of human and technical efficiency.

TABLE 6

\section{Casualties to Deep-sea Trawlers by age of VESSEL 1957-66}

\begin{tabular}{c|c}
\hline Trawlers older than 21 years & \\
No. of casualties & 47 \\
Casualty rate/100 vessel-years & 2.55 \\
\hline Trawlers $\begin{array}{c}\text { under } 21 \text { years old } \\
\text { No. of casualties } \\
\text { Casualty rate/100 vessel-years }\end{array}$ & $\begin{array}{c}43 \\
\end{array}$ \\
\hline
\end{tabular}

\section{Leadership}

There are exceptions to the general rule, one of which I shall take to illustrate the over-riding importance of leadership. In 1968 I made a trip in an oil-fired steam trawler which was built in 1954 and had avoided the scrap-yard mainly because of her excellent record, due to the competence and leadership of the man who had been her skipper for nine years. He had attracted a good crew which had stayed with him, and in all these years he had not had a serious casualty either to his vessel or to his men. Lord Hunt (1955) included humility among the 
qualities expected of a good leader. This is hardly a trait one expects in a man in charge of a sea-going vessel. 'Humility' he says 'is proof of integrity; it is difficult to retain but only if it is retained will a leader be willing to seek and take advice from others, particularly subordinates, to hear frank opinions and thus add to wisdom. How many mistakes have been made by leaders who have lost contact with the thoughts of their subordinates, whose pride has caused them to break this vital human link.' Such a quality of leadership would help to meet a demand from the Transport and General Workers Union that there should be crews' representatives on trawlers who would have the right to raise matters on safety with skippers, some of whom attempt to continue fishing in conditions which may endanger the deck crew. I was impressed by the humility of the man who skippered the trawler in which I went to sea and it was interesting that all but three of the men on this vessel regarded a crew's representative as unnecessary.

\section{Weather conditions}

Between 1957 and 1966 four vessels were lost during exceptionally severe weather conditions. If this period were extended from 1955 to 1968 it would include five more trawlers which capsized or were listed as missing, with the loss of virtually all their crews. The main cause of these losses is the formation of ice on the upper works by freezing spray which adds ice at an alarming rate leading to loss of stability and, ultimately, to capsizing. It occurs when there is a strong wind combined with low temperatures. Such conditions which may occur during the winter months off Iceland can be predicted by a prompt and reliable meteorological service. Since the war the Federal Republic of Germany has had an extensive support service for its fishing vessels. As they had no naval vessels to carry out fishery protection they converted a trawler to provide a civilian manned service. They now have three full-time support ships which cover the North Sea, Greenland, Newfoundland, Iceland, and the Norwegian coast for a fleet of 140 trawlers which is roughly a quarter of the size of the British fleet. Each ship carries a meteorologist and a specially trained meteorological wireless operator. They give routine weather forecasts for trawlers and maintain a direct personal contact by radio with skippers. These ships also have a sick berth and a small operating theatre, and carry a doctor and a sick berth attendant to treat injured and sick trawlermen; they have a workshop for the repair of trawler's machinery and equipment at sea. The advantages to the men and the industry generally of these two additional facilities are obvious.

In the period 1964-8 the fatal accident rates of German trawlermen show a downward trend and range between 3.8 and 3.1 per 1000 , whereas the corresponding rates of British trawlermen fluctuate between 1.5 and 8.5 per 1000 (Fig. 4). In the years when there were no disasters the British fatal accident rates compared favourably with the German rates. Since 1968 Britain has provided a support ship for its trawlers fishing off Iceland. If this service can be extended to other areas this type of vessel casualty should be eliminated.

\section{Hours of work and fatigue}

Fatigue may be indirectly responsible for vessel casualties caused by negligent navigation or errors of judgement. It is also likely to be an important cause of personal accidents.

Surprisingly little is known about the relationship between fatigue and work accidents even in shorebased industries. There is evidence from munition factories in the first world war that excessive fatigue among women working very long hours was responsible for a substantial proportion of their accidents (Vernon, 1945). Excessive muscular fatigue leads to loss of motor control and staggering and thus to slips and falls of the kind which befall climbers and potholers (Bell and Walters, 1969; Edholm, personal communication).

The deck-crew of a trawler is one of the few groups of men who still do long hours of heavy manual work. On a distant-water side trawler each member of the deck crew has six hours' continuous rest below during fishing and is on duty for 18 hours a day, with breaks for meals, or when their work is finished before the next haul. When catches are good or nets need repair, the periods of rest while on duty (known as gashes) are very short. On nearand middle-water trawlers there is usually no specified rest period during fishing. During a voyage on a near-water trawler I estimated that the deck crew had about six hours' broken rest in 24 but seldom more than two hours at a stretch. The deck crew of a side trawler are exposed to all weathers, to the constant vibration of the engines, and to working on a pitching, rolling deck. All these factors are conducive to fatigue. In a crew which had fished continuously for five days and nights, I became aware of the ashen-grey pallor of their faces, their slower movements, irritability, and chain-smoking, which reminded me of what I had seen among soldiers during the retreat to Dunkirk in 1940 (Schilling, 1966).

It takes three to five days to get to the fishing grounds in a distant-water trawler and about 24 hours in a near- or middle-water vessel. On the outward and homeward journeys work is relatively light and averages about eight hours a day for the deck crew, allowing recovery from the inevitable fatigue which follows 10 hard days of continuous 
fishing. They spend a short time ashore which may be only 60 hours. A man who has been away from his family and friends for three weeks or so wants to catch up with his social life and seldom spends much of his shore time resting. He may return to his ship for the next voyage as tired as when he entered port.

On stern trawlers both the hours and conditions of work are different from those on side trawlers. These vessels may go farther afield and spend up to seven days sailing to and from the fishing grounds. During fishing the deck crews work for 12 hours followed by six hours below. The men I spoke to were unanimous that these hours were preferable to the 18 hours on and six off on the side trawlers but, as some remarked, 'they are still long and you begin to feel very tired after a few weeks of continuous fishing'. These vessels, which freeze their catches and fill their holds to capacity, may be at sea for as long as seven weeks. There are likely to be disadvantages in an 18-hour cycle of work with sleep periods falling at different times of the day and night.

The Committee of Inquiry into Trawler Safety were convinced by their own observations and the evidence of crew members that fatigue is a major factor affecting the accident rate in deep-sea trawlers, and that if deck crews were assured of longer rest periods during fishing operations and longer shore leave between trips they would be better able to withstand the strains and hazards inherent in their work. Since there are at present no scientific criteria for selecting optimum rest periods, research on hours of work and fatigue in the deep-sea fleet was recommended. As an interim measure, immediate increases in the minimum rest periods for deck-hands were recommended. The committee sought to strike a balance between the need to allow more rest on the one hand and the limitations of what is realistic and economic on the other. Long rest periods, such as the 12 hours in 24, which are required by law on Icelandic trawlers, are likely to be economically impracticable and unpopular with fishermen who have a financial interest in catching as much fish as possible; and, as hunters, they would almost certainly dislike long periods of enforced idleness in a trawler. Fatigue would be replaced by boredom which could also have adverse effects on health and safety.

\section{Proposed reductions in working hours}

The CITS's recommendation for reducing hours of work during fishing, and for increasing shore leave, are modest and based on suggestions from trawlermen themselves, which, in the absence of scientific evidence, is likely to be the best criterion to use.

As there is a danger that a general instruction on increased minimum rest periods would remain a dead letter on some vessels the committee recommended that the Government should seek powers to lay down statutory requirements as soon as possible.

For distant-water vessels the recommendations are to increase rest periods from six to eight in 24 hours, with at least six hours of unbroken rest, and shore leave from 60 to 84 hours. These small changes may be enough to allow fuller recovery and thus prevent excessive fatigue. It would require a larger complement of deck-hands which would be a practicable proposition only for distant-water vessels. For near- and middle-water trawlers the eight hours' minimum rest in 24 is difficult to implement because of the lack of space for carrying a larger crew. These men are less at risk from accidents than men on the distant-water vessels but there should, even so, be significant benefits from following the committee's recommendation that they have six hours' unbroken rest in every 24 . Under present arrangements stern freezer trawlers have the equivalent of the eight-hour rest proposed for distant-water side trawlers, but investigations should be made of the effects on crews of the 18-hour cycle which may have adverse physiological and psychological effects.

\section{Technical developments}

The problem of fatigue can also be reduced by technological advances in the design of trawlers and their equipment. Already the White Fish Authority's Industrial Development Unit, working in collaboration with the industry, is developing net-hauling drums to make it easier to get gear aboard, and producing a gutting machine with conveyor systems which cut out the laborious task of doing this work by hand.

\section{Protective clothing}

The importance of the quality and design of fishermen's protective clothing became apparent during the study of skin disease among Lowestoft trawlermen (Newhouse, 1966). Well-designed protective clothing may help to reduce accidents as well as skin disease.

It has been the custom for fishermen to wear an unlined polyvinyl chloride smock, reaching to midcalf, with thigh-length sea-boots. This type of garment is cheap and easy to put on; nevertheless it has several unsatisfactory features in addition to its work edges causing skin lesions from chafing at the wrist. It is bulky and heavy, hampering quick movement - sometimes necessary to save life and limb. It is open at the neck and cuffs, affording little protection against wet and cold. It is negatively buoyant and thus offers no protection against drowning.

The TUC Centenary Institute of Occupational Health is collaborating with the Medical Research Council's Environmental Physiology Research Unit to produce a better garment and has enlisted the help 
of a clothing designer. The smock is warmer than a two-piece garment and this factor, as well as its low cost and ease of dressing, may account for its popularity. The aim is to design a trousered garment (Crockford, 1970) which will retain the advantages of the smock. With its improved mobility and lower wind resistance, the two-piece suit with cuffs to make it watertight should give the best all-round garment. Positive buoyancy will be incorporated by distributing buoyant material over the whole garment to avoid bulk and increase insulation. The inclusion of a high visibility red dye in the fabric will help to spot men who have gone overboard.

\section{Conclusion}

The factors which influence the health and safety of deep-sea fishermen are many and varied.There is the design, construction, and stability of the vessel and its equipment. Secondly, there is the selection and training of the crew, their health surveillance, methods and hours of work, and personal protection. Thirdly, there are the special services at sea such as weather forecasting and medical and technical aid provided by support ships. Finally, there is the less tangible, but overriding, influence of management and industrial relations which ultimately decides the company's health and safety policy and the extent to which it is put into practice. 'Safety cannot be considered in isolation from other major factors which determine the success and efficiency of an industry including in particular the management of men. If policies on accident prevention are to take fulleffect ... the industry's personnel policies will have to be reexamined in various fields, including the recruitment and training of labour, its career structure and the relations between management and crews (HollandMartin, 1969).

Medicine has an important part to play by detecting hazards and assessing their effects on health and safety. A physician's study of skin disease in trawlermen led to the investigation of their fatal accidents and the discovery that their mortality rates had been grossly underestimated. Unlike the National Health Service, an occupational health service can deal with the special problems of selecting men and young persons for this arduous work and re-assessing their fitness after sickness and injury. Together with the medical service on the support ships an occupational physician can provide an invaluable source of statistical and epidemiological data on the health of fishermen.
There is a need for research into the prevalence and causes of coronary heart disease and hypertension, into fatigue and protective clothing and other factors affecting the health and safety of crews. This kind of research may be of general scientific interest by adding to knowledge of human performance under stress.

Possibly more than anyone else the occupational physician is able to influence management to adopt an enlightened policy on health and safety.

Much of this lecture is based on experience gained as a member of the Committee of Inquiry into Trawler Safety. I wish to thank the Registrar General of Shipping and Seamen, the Medical Statistics Branch of the National Coal Board, and H.M. Factory Inspectorate for providing figures on accident rates. I am grateful to my wife and to members of my staff for help in preparing the manuscript.

\section{References}

Bell, C. R., and Walters, J. D. (1969). Reactions of men working in hot and humid conditions. J.appl. Physiol.,27, 684-6.

Crockford, G. W. (1970). Protective clothing for fishing crews. Textile Institute and Industry, 8, 121-124.

Fleck, Sir Alexander (Chairman) (1961). Report of the Committee of Inquiry into the Fishing Industry. Cmnd. 1266. H.M.S.O., London.

Holland-Martin, Sir Deric (Chairman) (1969). Trawler Safety: Final Report of the Committee of Inquiry into Trawler Safety. Cmnd. 4114. H.M.S.O., London.

Hunt, Sir John (1955). Commemoration Oration, King's College, London.

Lithgow, Sir William (1968). Shipbuilders and safety at sea. Letter to The Times - 2nd February, p. 9.

March E. J. (1953). Sailing Trawlers. Percival, Marshall, London.

Moore, S. R. W. (1969a). The occupation of trawl fishing and the medical aid available to the Grimsby deep-sea fisherman. Brit. J. industr. Med., 26, 1-24.

- (1969b). The mortality and morbidity of deep sea fishermen sailing from Grimsby in one year. Brit. J. industr. Med., 26, 25-46.

Newhouse, M. L. (1966). Dogger Bank itch: survey of trawlermen. Brit. med. J., 1, 1142-1145.

Ogle, W. (1885). Supplement to 45th Annual Report of the Registrar-General (1871-1880), pp. iii-1xiv. H.M.S.O., London.

Registrar General (1958). Decennial Supplement, England and Wales 1951, Occupational Mortality, Part II. Vol. 1: Commentary. H.M.S.O., London.

Schilling, R. S. F. (1966). Trawler fishing: an extreme occupation. Proc. roy. Soc Med., 59, 405-410.

- W Walford, J., and Wood, R. (1969). The mortality of fishermen in Great Britain. In Trawler Safety, Cmnd. 4114, Appendix B, pp. 117-125. H.M.S.O., London.

Tunstall, J. (1962). The Fishermen. MacGibbon and Kee, London.

Vernon, H. M. (1945). Prevention of accidents. Brit. J. industr. Med., 2, 1-9.

Received for publication April 16, 1970. 